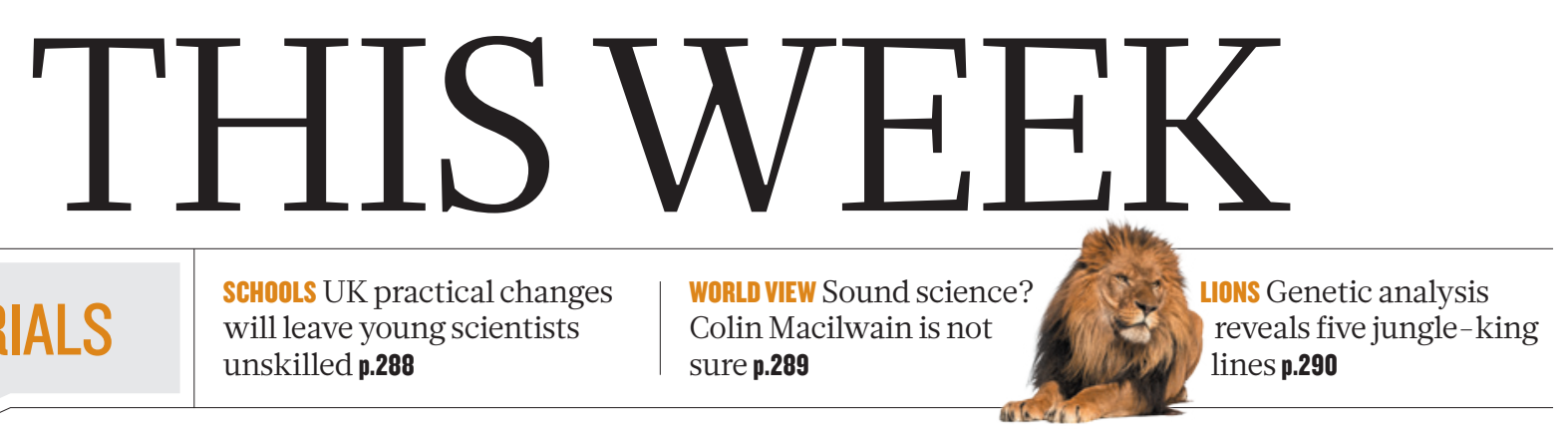

EDITORIALS will leave young scientists unskilled $\mathbf{p . 2 8 8}$

WORLD VIEW SOund Science? sure p.289

\title{
The democracy carousel
}

\author{
European law has allowed citizens to force a debate on human embryonic stem cells less than a year \\ after the previous one. This fruitless democratic exercise has left scientists spinning in uncertainty.
}

$\mathrm{W}$ inston Churchill famously said that democracy was the worst form of government, except for all the others. Scientists in the European Union (EU) who work with human embryonic stem cells have more reasons than most to see the systems's flaws. Yet again, they have been forced to discuss and defend the purpose and ethics of their work. Once more, they must watch as possible curbs on their research are proposed.

The trigger this time is the latest in a series of European Citizens' Initiatives (ECIs): petitions that were introduced in 2012 and that automatically prompt a formal public hearing in the European Parliament when they reach more than 1 million signatures across at least seven EU countries. The 'One of Us' petition, which was signed by more than 1.7 million people across all $28 \mathrm{EU}$ countries, calls for a ban on financing any activity that requires the destruction of human embryos, directly or indirectly - so in addition to forbidding EU funding for work on human embryonic stem cells, it proposes a block on aid for agencies that offer abortion advice.

If this topic sounds rather familiar, that's because the same sensitive issue was extensively discussed by the European Parliament in 2006, and again in 2013, before the launch of the multi-billion-euro Seventh Framework and Horizon 2020 research programmes, respectively. In both cases, and after wide consultation, the EU decided to fund such research, provided that approved projects used existing human embryonic stem-cell lines and respected Europe's variable national laws. Yet, in a hearing on 10 April, the European Parliament dutifully rehearsed the same arguments that had led to its previous decisions.

The atmosphere in the crowded auditorium was less decorous than European parliamentarians are used to. Scornful booing erupted, for example, when the parliament's legal-committee representative, Françoise Castex, declared that there was no reason in law to stop funding human embryo research.

The European Commission must prepare a report responding to the One of Us initiative before 28 May, addressing whether any EU legislation could or should be changed in response. It should not.

European scientists have been unsettled by the One of Us initiative, and also by the prospect of a parliamentary hearing of another ECI, 'Stop Vivisection', that calls for the 2010 legislation on the use of animals in research to be replaced by a new directive banning all animal experimentation. That hearing is likely to take place in September.

What is the value of these new efforts in participatory democracy? The general aim sounds noble; it is, of course, good to be able to hold power to account and to involve citizens in setting agendas for discussion. But in practice, and certainly in the case of these two initiatives, they have little democratic merit. The uses of human embryonic stem cells and animals in research have both been discussed very recently. The 2010 animal legislation represented a hard-fought-for compromise that was agreed by EU member states and the European Parliament only after more than a decade of debate involving consultation

with all sides. The even-more-recent legislation on funding of research with human embryonic stem cells also represents a compromise in which all sides, including the representatives of One of Us, had their say. To allow a group representing less than $0.4 \%$ of the EU's 500 million or so inhabitants to reignite the debate after such a short time seems more of an anti-democratic act than an enlightened one. Worse, the commission's report will of necessity have to repeat the arguments that led to the 2013 decision to fund some research using

\section{"What is the} value of these new efforts in participatory democracy?" represent direct democracy - there is no obligation to change rules in response to them, unlike the recent Swiss referendum curbing immigration, which is now making great difficulties for scientists (see Nature 506, 277; 2014). But they still create an undesirable atmosphere of uncertainty. They mean that researchers will have to increase their efforts to keep the achievements of science in the headlines.

When it comes to complex, highly emotional issues, passionate minority groups can easily and quickly drum up well-supported petitions in a way that scientists cannot (although patient groups could, and perhaps should, think about doing so). Scientists and advocates can, however, build a counterbalance by continuing to present their work as necessary to the well-being of all members of society however they may vote..

\section{Cancer crossroads}

\section{Efforts to understand cancer genomes should take on a fresh focus.}

$S_{\text {r }}^{\text {in }}$ ince the discovery of the first cancer-causing genes in the 1970s, researchers have been eager to catalogue the mutations that can our understanding of what causes the disease - and how to treat it.

The latest progress towards that goal was on display last week, when 18,400 people descended on San Diego in California to attend the annual American Association for Cancer Research meeting. Researchers showed how patterns of mutation can be used to track down the agent that caused them - sunlight, for example, leaves a footprint that differs from a cancer-causing viral infection. Another team had 